\title{
GUERRA TOTAL E A ORDEM JURÍDICA INTERNACIONAL
}

\author{
http://dx.doi.org/10.21527/2176-6622.2019.51.153-164
}

Recebido em: 14/3/2019

Aceito em: 19/4/2019

Sidney Cesar Silva Guerra

Pós-Doutorado pelo Centro de Estudos Sociais da Universidade de Coimbra e pelo Programa Avançado em Cultura Contemporânea da Universidade Federal do Rio de Janeiro. Doutorado e Mestrado em Direito. Especialização em Direito Internacional pela Academia de Direito Internacional de Haia. Especialização em Direito Humanitário pelo Comitê Internacional da Cruz Vermelha. Especialização em Direito Internacional pelo Comitê Jurídico Interamericano da Organização dos Estados Americanos (OEA). Professor-adjunto IV da Faculdade Nacional de Direito da Universidade Federal do Rio de Janeiro. Professor do Programa de Mestrado em Direito da Universidade Católica de Petrópolis. Professor-convidado de várias Universidades Estrangeiras. Possui experiência na área de Direito, com ênfase em Direito Internacional Público, Direitos Humanos e Direito Ambiental. sidneyguerra@terra.com.br

Lucas Leiroz de Almeida

Possui experiência na área de Direito, com ênfase em Direito Internacional. Ilucasleiroz@gmail.com

\section{RESUMO}

Desde os seus primórdios, a humanidade sempre conviveu com o conceito de guerra. A intolerância, o egoísmo e a falta de amor ao próximo, conduziram a raça humana para muitas contendas que, indubitavelmente, acabam por resultar em danos irreversíveis para milhares de pessoas. Na guerra não se faz outra coisa senão lutar, e essa luta é feita com armas. Houve, portanto, a necessidade de se estabelecer regramento próprio para a mesma na esfera do Direito internacional. A tentativa de se abolir a guerra do seio da sociedade mundial é extremamente difícil, fazendo com que os Estados adotem medidas para minimizar as atrocidades praticadas quando da eclosão de um conflito bélico, surgindo as normas provenientes do jus in bellum. Iniciados os atos de hostilidade, o jus in bellum é imediatamente acionado na ordem jurídica internacional, tendo em vista ser o conjunto de normas que deverá ser observado durante o conflito, incluindo o tratamento aplicado pelos Estados beligerantes aos enfermos, feridos, prisioneiros, população civil, assim como aos combatentes e não combatentes. $O$ jus ad bellum (direito à guerra) consiste no direito de fazer a guerra quando esta se apresentar com subsídios para sua legitimação (justa). Hodiernamente, o direito à guerra se apresenta na ordem jurídica internacional como um ilícito, salvo duas hipóteses previstas na Carta das Nações Unidas: legítima defesa coletiva ou individual e autorização do uso da força junto ao Conselho de Segurança das Nações Unidas. Neste estudo, o principal objetivo será o de apresentar uma abordagem do ordenamento jurídico internacional contemporâneo a partir do conceito militar, histórico e geopolítico de guerra total (Totaler Krieg). O advento deste novo tipo de guerra no século 20 e as experiências registradas entre 1914 e 1945, fornecem valiosos dados para a compreensão da natureza do Direito Internacional em sua forma moderna.

Palavras-chave: Direito internacional. Guerra total. Relações internacionais. Geopolítica.

\section{TOTAL WAR AND THE INTERNATIONAL LEGAL ORDER}

\section{ABSTRACT}

Since its beginning, humanity has always lived with the concept of war. Intolerance, selfishness, and a lack of love for others have led the human race to many strife that undoubtedly results in irreversible harm to thousands of people. In war there is nothing else but fighting, and this fight is done with weapons. Therefore, there was a need to establish its own rules in the sphere of international law. Attempting to abolish warfare within world society is extremely difficult, so the states adopt measures to minimize the atrocities practiced in the outbreak of a war conflict, emerging the rules of the jus in bellum. Initiated the acts of hostility, jus in bellum is immediately triggered in the international legal order, in order to be the set of rules that should be observed during the conflict, including the treatment by belligerent states to the sick, wounded, prisoners, civilian population, as well as combatants and noncombatants. Jus ad bellum (right to war) is the right to make war when it comes with subsidies for its (just) legitimation. Today, the right to war presents itself in the international legal order as an illicit one, except for two hypotheses provided for in the United Nations Charter: legitimate collective or individual self-defense and authorization of the use of force before the United Nations Security Council. In this study, the main objective will be to present an approach to the contemporary international legal system from the military, historical and geopolitical concept of total war (der Totale Krieg). The advent of this new type of war in the 20th century and the experiences registered between 1914 and 1945 provide valuable data for understanding the nature of international law in its modern form.

Keywords: International law. Total war. International relations. Geopolitics.

\section{SUMÁRIO}

1 Introdução. 2 Breve contextualização histórica do Direito internacional. 3 Da guerra e da guerra total. 4 De Vestfália a Nuremberg. 5 Considerações finais. 6 Referências. 


\section{INTRODUÇÃO}

Desde tempos imemoriais o homem está habituado à prática da guerra. São inumeráveis as razões pelas quais diferentes grupos humanos se enfrentam com apelo à violência física. Uma recente descoberta arqueológica de pesquisadores no Quênia registrou a mais antiga ocorrência de um massacre entre grupos humanos. ${ }^{1} \mathrm{O}$ conflito, especula-se, se deu entre dois diferentes grupos de caçadores em busca de recursos naturais e territórios. Entre os esqueletos são encontrados mulheres e crianças, sugerindo os níveis de violência já alcançados nas pré-históricas modalidades de guerra.

Ao iniciar com os caçadores nômades primitivos até a bomba atômica, uma longa tradição bélica foi construída por todos os povos. Líderes políticos e militares, teólogos, poetas e acadêmicos das mais diversas áreas do conhecimento, se propuseram a estudar, narrar, interpretar, teorizar e inovar a guerra. Desde os épicos homéricos às Tempestades de Aço de Ernst Jünger, toda sorte de esforços é empregada em descrever a guerra. A valorização da figura do herói tem sido, em tempos remotos, uma marca singular das narrativas da guerra. Pode-se afirmar que até o século 20 essa figura ainda possuía em si alguma espécie de base lógica efetiva, premiando o combatente corajoso, vitorioso, destemido e leal, independente do lado pelo qual combatia - desde uma perspectiva clássica do heroísmo. O progresso técnico e seus desdobramentos bélicos, contudo, trouxeram consigo uma mudança radical no modo de se interpretar a guerra, uma vez que, na era da artilharia pesada, dos bombardeios aéreos e das armas de destruição em massa, torna-se praticamente impossível evitar o ofuscamento de qualquer figura heroica ou destemida. A guerra progressivamente adquire um caráter impessoal. O combate corporal e as mobilizações de infantaria gradativamente cedem espaço ao poder mortífero dos ataques aéreos e das armas de destruição em massa, que extinguem toda possibilidade de luta pessoal, ofuscando o heroísmo e agregando à guerra um caráter de pura aniquilação.

A transição da guerra em seu conceito parcial tradicional para uma dimensão total, tem suas origens ainda nos séculos 18 e 19, ${ }^{2}$ mas seu estopim se deflagra com o advento das Guerras Mundiais entre 1914 e 1945, naquilo que Eric Hobsbawn chamaria de Guerra Mundial de $31 .{ }^{3}$ Conceitos outrora bem-demarcados, tais quais campo de batalha e metrópole e combatente e civil, são flexibilizados, caracterizando uma nova modalidade de guerra, praticamente sem limites, com uma mobilização plena de todos os recursos do país para fins bélicos e absolutamente tudo o que se remete ao agrupamento humano oponente - Estado-Nação, movimento beligerante ou correlato - adquire um caráter inimigo, incluindo a população não militar, as cidades, a ideologia, a história e a cultura. O objetivo da guerra é transferido da intenção de submeter um grupo inimigo a uma vontade política para a busca por sua total aniquilação, seu completo extermínio.

O desfecho da Guerra Total no século 20 não poderia exigir outra reação da sociedade internacional senão um forte movimento pela paz e pela segurança internacional, contrário a qualquer forma de conflito armado e disposto a sacrificar liberdades básicas dos Estados-Nação, até então os únicos atores do cenário internacional e os grandes responsáveis pelas Guerras Mundiais e por toda a catástrofe delas decorrente. A fracassada Liga das Nações prenunciou o sucesso da Organização das Nações Unidas, que em nada mais consistiu do que na criação de um Leviatã hobbesiano na esfera internacional, isto é, uma fuga de uma espécie de estado de natureza das nações. Desde então, o mundo westfaliano teve sacramentado seu fim e a transição de um direito internacional de Estados Nacionais para um direito internacional de natureza universalista e leviatânica, sendo transferido o jus belli para um Conselho de Segurança internacional. Longe, porém, de significar qualquer evidência empírica do mito jurídico da igualdade política de todas as nações, a nova fase do direito internacional estabelecida pelo pós-guerra nada mais representou do que a entronização dos vencedores e sua justiça sobre as nações derrotadas, cujo símbolo atemporal se desenhara na realização dos controversos Julgamentos de Nuremberg, que, longe de representar uma justiça real e uma compensação dos efeitos da

\footnotetext{
Ver: GORMAN, James. Prehistoric Massacre Hints at War Among Hunter-Gatherers. The New York Times. 21 de Jan. de 2016. Disponível em: https://www.nytimes.com/2016/01/21/science/prehistoric-massacre-ancient-humans-lake-turkana-kenya.html. Acesso em: 20 fev. 2019.

2 Para maior atenção ao tópico, ver: BELL, David. The First Total War: Napoleon's Europe and the Birth of Warfare as We Know It. 1 ed. Boston, Houghton Mifflin Co., 2007.

3OBSBAWN, Eric. A era dos extremos: o breve século XX. 1914-1991. 2 ed. São Paulo: Companhia das Letras. 1995. p. 30.
} 
Guerra, marcaram simplesmente uma justiça dos vencedores num tribunal militar de exceção, desprovido de princípios básicos de justiça, levando a julgamento réus acusados de atos que, ao tempo de seu cometimento, não constituíam crimes (ex pos facto).

Em suma, historicamente as nações têm aberto mão de uma parcela significativa de sua soberania em prol do gozo da parcela restante com maiores níveis de estabilidade e segurança. Se, porém, ainda havia algum tipo de equalização de poderes no sistema bipolar inaugurado pela Guerra Fria sob o antagonismo de duas potências nucleares, com a queda definitiva da URSS e a unipolarização geopolítica sob o jugo americano-ocidental e liberal, esse estado de segurança se deteriora em prol de uma completa subordinação universal à pax americana. Recentes eventos na esfera geopolítica têm denotado mais um estado de transição desde o advento da era Putin na Rússia e a ascensão avassaladora da China, tornando possível a especialistas que hoje seja especulado o nascimento de um mundo multipolar, quando a figura do pluriversum ${ }^{4}$ seja novamente passível de significação jurídica e política. Enquanto esse processo ainda se desenha sem real prejuízo da ordem vigente, cabe a pesquisadores do Direito Internacional e das Relações Internacionais o estudo das origens da ordem vigente e uma análise comparativa das conclusões obtidas com as linhas que vão, aos poucos, se delineando para a formação de um novo ordenamento. A isto se propõe o presente estudo.

\section{BREVE CONTEXTUALIZAÇÃO HISTÓRICA DO DIREITO INTERNACIONAL}

Compreender a história do Direito Internacional é um importante ponto para o desenvolvimento do presente estudo. Prenúncios de um Jus Gentium podem ser encontrados ao longo da Antiguidade e da era pré-global como um todo. Porém, como assinala Carl Schmitt (2008), porém, os impérios pré-globais tratavam o mundo desde uma perspectiva mítica, dado o total desconhecimento da vastidão territorial dos continentes e oceanos, de modo que o Direito Internacional pré-global é internacional em um sentido incompleto e controverso, vindo este fato a mudar apenas com o desbravamento dos mares e o surgimento de verdadeiras potências terrestres e continentais em oposição a potências marítimas e globais. ${ }^{5}$

$\mathrm{Na}$ Idade Média, ainda em Carl Schmitt, ${ }^{6}$ o direito das gentes adquire um caráter indissociável da esfera da comunidade cristã europeia, o que se chamou de Respublica Christiana, isto é, a comunidade de povos sob o jugo da auctoritas spiritualis do Papa de Roma. A guerra, dentro das circunscrições territoriais da Respublica Christiana, não abalava sua estrutura e não possuía o mesmo significado material e espiritual da guerra direcionada aos povos estrangeiros e infiéis, cuja guerra e anexação territorial por um soberano cristão era legítima (justum bellum) enquanto abençoada pela autoridade papal.

A ideia de Respublica Christiana é indissociável do conceito de Katechon, da possibilidade de se evitar a vinda do Anticristo. A figura do Imperador e sua aliança espiritual adquirem essa função mística e escatológica tanto no catolicismo romano da Idade Média ocidental quanto na Ortodoxia Oriental durante o Império Bizantino e, posteriormente, no Czarismo russo. As bases estariam nas próprias Escrituras, conforme 2 Tessalonicenses 2:6-2:7 (BÍBLIA, 1969). ${ }^{7}$ Esse caráter metafísico, segundo o qual o político se fundamenta na missão de evitar o fim dos tempos com a chegada do Anticristo - é gradualmente desfeito com a desintegração do conceito de Imperium e o advento da Idade Média tardia, onde, após seu apogeu, o sistema socioeconômico e jurídico do medieval entra em decadência, abrindo espaço para o surgimento do Estado e da Modernidade.

A deterioração do Direito das Gentes medieval prossegue com o advento da Modernidade, havendo o surgimento efetivo de uma nova ordem jurídica apenas com a Paz de Vestfália (1648), que pôs fim à Guerra dos Trinta Anos (1618-1648) e reordenou a Europa em uma sociedade de Estados-Nação, diminuindo consideravelmente o poder da Igreja Católica e promovendo uma guinada gnosiológica que sedimentaria as bases para todo o pensamento jurídico e político contemporâneo.

\footnotetext{
Sobre o pluriversalismo jurídico, ver: TEIXEIRA, Anderson Vichinkeski. Teoria pluriversalista do Direito internacional. 1. ed. São Paulo: WMF Martins Fontes, 2011.

5 SCHMITT, Carl. El Nomos de la Tierra en el Derecho de Gentes del "Jius Publicum Europaeum". Buenos Aires: ., 2005. p. 30-36.

6 Ibidem, p 36-48.

"E agora vós sabeis o que o detém, para que a seu próprio tempo seja manifestado. Porque já o mistério da injustiça opera; somente há um que agora o retém até que do meio seja tirado" (2 Tes. 2:6,7). Historicamente, aquele que detém o Anticristo tem sido interpretado como o Imperador Cristão.
} 
O mundo vestfaliano perdura, sobrevivendo à era napoleônica (1799-1815), e entra em crise paralelamente com o advento do imperialismo liberal-burguês do capitalismo industrial. Para entender o desenvolvimento do Estado e da ordem internacional por sua figura gerada, é necessário também levar em consideração a gestação do capitalismo no estopim da Modernidade e do requerimento por parte da burguesia da chancela do Estado-Nação. A figura do Estado fora indubitavelmente necessária à classe burguesa em seu processo de afirmação histórica e de secularização da ordem europeia na transição do medievo para a Modernidade. Esse cenário, porém, começa a mudar com a necessidade de expansão dos mercados pelas potências capitalistas, marcado pelo avanço imperialista em terras africanas e asiáticas. Pode-se afirmar que, desde uma perspectiva crítica, o declínio da ordem dos Estados Nacionais tem seu início com as movimentações imperialistas entre os séculos 19 e 20.

Também entre fins do século 19 e começo do 20 surgem aqueles que até então seriam os maiores símbolos do Direito Internacional, a saber, as primeiras Convenções de Paz da Haia e as Convenções de Genebra, que lançam as bases do Direito Internacional Humanitário, ${ }^{8}$ que consiste nas regras universais de respeito à vida humana em situação de combate e estabelecem as leis e os crimes da guerra. O período de paz do qual disfrutava a Europa na época de expansão imperialista do capitalismo industrial e de declínio da ordem dos Estados nacionais, tornaram possível estes que seriam, até então, os maiores adventos do direito em esfera internacional: o estabelecimento de regras referentes à prática da guerra positivadas por tratados internacionais celebrados entre potências soberanas. Logo, porém, seriam abaladas todas as conquistas do Direito Internacional com o estopim da Guerra Mundial e a reconfiguração geopolítica e jurídica da Europa e de todo o planeta.

Como menciona Hobsbawn, a palavra "paz" deve significar "antes de 1914", havendo, depois desse ano, algo que já não mais seria digno desse nome. ${ }^{9}$ A grande Guerra dos Trinta Anos do século 20, tal qual sua predecessora do século 17, assume um papel fundamental na substituição de um ordenamento jurídico internacional por outro. Com as Guerras Mundiais surge a Guerra Total, um conceito radical de guerra que demanda a total mobilização de esforços para os fins do combate. A participação dos civis se torna efetiva, as cidades confundem-se aos campos de batalha e toda a nação está envolta na Guerra em menor ou maior grau. $\mathrm{O}$ cenário que então se delineia é o da mais completa catástrofe. É inaugurada a era do massacre. ${ }^{10} \mathrm{O}$ século mais sangrento da história da humanidade muda para sempre o curso da história.

Com a Primeira Guerra Mundial (1914-1918), em sua essência, uma guerra imperialista, a ordem dos Estados nacionais, já em declínio, começa a desmoronar. Com o fim do conflito e a derrota da Alemanha, restava clara a todos os Estados envolvidos nos combates a necessidade de se desenvolver o Direito Internacional para além de todos os limites até então alcançados, uma vez que o maior desejo de toda a comunidade internacional, a partir daquele momento, era evitar que novos conflitos de mesma magnitude ocorressem. Em 1919 começam, então, as reuniões em torno de um acordo para pôr um fim definitivo ao conflito, cujo armistício ocorrera no ano anterior, e estabelecer um planejamento com fins de impedir sua retomada ou repetição. Para isso, surge a Liga das Nações, com o objetivo de garantir a paz entre os povos. Em paralelo, é assinado o polêmico Tratado de Versalhes, que explicitamente responsabiliza o Reich alemão pela Guerra e Ihe impõe uma série de sanções e restrições, tais quais a perda de territórios, o pagamento de uma desproporcional indenização pelos danos do conflito e uma grande restrição em seu contingente militar. Para os alemães, o Tratado é recebido como uma imposição (Diktat), e ao povo germânico representa apenas vergonha, humilhação e todo um rol de mazelas sociais que viriam a se suceder sob a impotente República de Weimar.

Sobre o Tratado de Versalhes, em outra oportunidade ${ }^{11}$ assentou-se que, diferentemente do que acontecia quando da celebração de Conferências de Paz, este não estabeleceu o encontro entre vencedores e vencidos, haja vista que os Estados derrotados não participaram da referida Conferência, caracterizando a "paz dos vencedores". A paz estabelecida com o Tratado de Versalhes, como se pode evidenciar, ocorreu com os

\footnotetext{
8 GUERRA, Sidney. Curso de direito internacional público. 11. ed. São Paulo: Saraiva, 2017.

9 HOBSBAWN, Eric. A era dos extremos: o breve século XX. 1914-1991. 2. ed. São Paulo: Companhia das Letras, 1995. p. 30.

${ }_{10}$ Ibidem, p. 29-60. Ver também: SINGER, David. The Wages of War 1816-1965: A Statistical Handbook. Nova York; Londres; Sidney; Toronto: John Wiley \& Sons, 1972. p. 66, 131.

${ }^{11}$ GUERRA, Sidney, op. cit., p. 360.
} 
países que venceram a guerra, excluindo-se, então, os derrotados. Levando-se em consideração que eles não foram convocados para participar como signatários do referido tratado, infere-se que foram deixados resquícios para futuros conflitos, tendo em vista ter ficado enraizado, no coração dos derrotados, a fumaça do ódio, da revolta e do repúdio".

Indubitavelmente que as condições humilhantes impostas à Alemanha pelo Tratado de Versalhes contribuíram consideravelmente para a formação de um nacionalismo hostil entre os alemães. Esse sentimento seria posteriormente aproveitado por Adolf Hitler e contribuiria para o advento do nazismo e do Terceiro Reich. A crise mundial do liberalismo, deflagrada pela Grande Depressão em 1929, que levou nações inteiras à falência, também foram grandes fatores propulsores da avalanche totalitária na Europa. Com populações inteiras insatisfeitas e céticas quanto ao moribundo Estado liberal e temerárias quanto ao comunismo soviético, o resultado não poderia ser outro senão um solo fértil para os discursos extremistas de um ultranacionalismo radical e violento que se apresentava como uma terceira via política.

Em 1939 deflagra-se a Segunda Guerra Mundial, que se estenderia até 1945, envolvendo, de uma forma ou de outra, todos os continentes e, praticamente, todos os países do globo. Ainda que se fale em uma "Primeira Guerra Mundial", este conflito envolveu efetivamente apenas os limites do continente europeu, e entre 1939 e 1945, pela primeira vez na história, o mundo entrou em guerra, culminando com a denominada "era do massacre" para muito além de todos os limites e especulações que havia alcançado o conflito antecedente. O saldo de cerca de 54 milhões de mortos ${ }^{12}$ rendeu ao século 20 a digna e vergonhosa marca de século mais sangrento da história humana. Não bastassem as divulgadas barbáries perpetradas pelas potências do Eixo, a exemplo do Holocausto e das perseguições políticas e raciais, as nações aliadas não deixaram a desejar em termos de desumanidade, como se pôde ver em episódios como o bombardeio de Dresden, a onda de estupros de mulheres alemães com a vitória soviética, e as desnecessárias e brutais explosões das duas bombas atômicas em Hiroshima e Nagasaki. No fim, todas as partes envolvidas na Segunda Guerra Mundial concordaram em fazer do conflito o de maiores índices de brutalidades.

Com o término dos conflitos e a vitória aliada, tal qual na Primeira Guerra Mundial, as potências vencedoras consentiram em estabelecer uma punição aos derrotados, que foram novamente responsabilizados pelas hostilidades. No afã de punir os alemães, fora estabelecido, em Nuremberg, entre 1945 e 1946, o Tribunal Militar de Nuremberg, cujo fim seria o julgamento de uma lista de nomes de alemães cujos critérios de seleção seguem obscuros. A lista não englobava um número incerto de alemães que, responsáveis por eventos de grande relevância na Guerra, aceitaram, com a rendição, colaborar com as forças aliadas contra a Alemanha, como militares e cientistas radicados nos Estados Unidos da América. Igualmente, não houve um planejamento em se capturar alemães desaparecidos, que fugiram para diversas partes do mundo, e cujo paradeiro permanece em obscuridade.

Os problemas com o Tribunal de Nuremberg não terminam na seleção de réus, mas se estendem à formulação da Corte. Não havia, antes dos Julgamentos, qualquer tipo de lei que tornasse criminosos os atos perpetrados pelos acusados, uma vez que à época ainda prevalecia a soberania dos Estados nacionais ante um direito internacional nascituro. Nuremberg fez e executou a própria lei, em incidência ex post facto, num cenário tal em que os vencedores de um conflito criaram, findados os fatos, normas que os condenassem retroativamente, acusando, julgando e condenando homens que, apesar de toda a conhecida desumanidade de seus atos, não estavam a cometer crimes à época de sua execução.

Não sendo de muita relevância a questionabilíssima legitimidade dos Julgamentos de Nuremberg, o que realmente importa ao presente estudo é o legado de sua ocorrência. Nuremberg inaugura uma nova fase do Direito Internacional, em que um seleto número de nações vencedoras acumula o monopólio jurídico internacional, tendo, em decorrência de sua vitória, força suficiente para ditar regras e impor suas vontades políticas no cenário internacional. Dessas nações, as duas que prevaleceram nesse jogo de poder foram os Estados Unidos da América e a União das Repúblicas Socialistas Soviéticas, que, até 1991, dividiram o mundo em uma geopolítica bipolar.

\footnotetext{
12 Idem.
} 


\section{Debate}

Outro efeito que não pode deixar de ser mencionado é a conscientização coletiva das nações sobre a periculosidade da soberania irrestrita dos Estados Nacionais, posto que, à época de sua ocorrência, todos os crimes contra a humanidade, perpetrados pelos prepostos dos Estados beligerantes, eram inequivocamente legais - e é justamente aí que se encontra toda a fragilidade da legitimidade dos Julgamentos de Nuremberg. Isso levou a um consentimento dos países em se estabelecer uma nova organização internacional - visto que, como era previsível desde o estopim da Segunda Guerra Mundial, a Liga das Nações não resistiria a seu fracasso em estabelecer a paz mundial -, que asseguraria aos povos um mundo de maior pacificidade e de direitos mínimos universais. A partir daí, os Estados concebem uma nova Organização Internacional - a Organização das Nações Unidas (ONU).

Com o advento das Nações Unidas encerra-se o ordenamento jurídico internacional vestfaliano e inaugura-se uma ordem jurídica internacional, em que o direito sobre a guerra passa às mãos de um Conselho de Segurança ocupado por países de grande relevância geopolítica.

Após a queda do comunismo soviético em 1991, a ordem bipolar se transfigura em um ordenamento geopolítico unipolar, iniciando uma era de pleno poder americano-ocidental, que, por sua vez, implica maior capacidade de violar e criar normas internacionais, legitimando atos ilegais dentro da esfera internacional, tal como se pôde notar em episódios como a Invasão do Iraque (2003) e a Guerra do Kosovo (1998-1999). ${ }^{13}$ Assim, a sucessão de eventos na seara geopolítica, desde o surgimento das Nações Unidas, denota a indubitável relação de subordinação do Direito Internacional para com a Realpolitik, inaugurada em Nuremberg.

\section{DA GUERRA E DA GUERRA TOTAL}

Carl von Clausewitz (2007), o gênio prussiano da guerra, define a mesma como $o$ ato de força para compelir o inimigo a realizar a nossa vontade,$^{14}$ ou, nada além de um conflito em larga escala.$^{15}$ Historicamente, as guerras têm servido como instrumentos políticos utilizados pelos agentes beligerantes em uma mútua tentativa de submissão do oponente às suas respectivas vontades. Como diria Carl Schmitt, o meio político extremo. ${ }^{16}$ Essa característica "limitada" da guerra marcou, sobretudo, a era moderna e o sistema dos Estados Nacionais, conforme corrobora Hans Morgenthau, em A Política entra as Nações (1948).

A guerra parcial, ou limitada, é, por excelência, a guerra entre Estados Nacionais soberanos; o conflito racional entre agentes estatais beligerantes com oponíveis vontades políticas; o duelo estendido à proporção das hostes; a expressão bélica perfeita do sistema individual-estatal e do ordenamento jurídico proto-liberal de fronteiras artificiais atomizadas. Essa ordem internacional perdura ao longo da era vestfaliana, caindo por terra com o advento das guerras mundiais no século 20. Surge, então, a Guerra Total. Este estranho fenômeno transfigura a natureza da guerra, transformando-a de um conflito parcial e incontestavelmente limitado por uma série de fatores materiais e imateriais, em um confronto sem medidas, irrestrito, irracional e de plena mobilização de esforços. Morgenthau (2003) define em quatro os fatores pelos quais a guerra se convertera em um conflito total:

Já assinalamos que a guerra, em nossa época, se tornou total sob quatro aspectos distintos, com respeito: (1) à parcela da população completamente identificada, em suas emoções e convicções, com as guerras de seu país;

(2) ao segmento da população que participa da guerra; (3) ao contingente da população afetada pela guerra; e

(4) aos objetivos perseguidos pela guerra (2003, p. 679).

Ainda que se determinem primórdios e paralelos nas Guerras Napoleônicas, é a Primeira Guerra Mundial o conflito que inaugura a era da Guerra Total. Nunca antes uma guerra registrara tão expressiva quantidade de mortos e tão larga escala de potencial de destruição e aniquilação. Para ingleses, franceses e alemães, a Grande Guerra foi a mais completa catástrofe. Para os tardios interventores dos Estados Unidos da América, as dimensões foram bem menores. São justamente esses fatores que permitiram a queda da hegemonia da

\footnotetext{
${ }^{13}$ Sobre o tema, ver: ZOLO, Danilo. La Justicia de los Vencedores: de Nuremberg a Bagdad. Madrid: Ed. Trotta, 2007. CASSESE, Antonio. II Processo a Sadam e i Nobili Fini della Giustizia. In: La Repubblica, 19 out. 2005.

${ }^{14}$ VON CLAUSEWITZ, Carl. On War. Oxford: Oxford University Press, 2007. p. 13.

15 Ibidem.

${ }^{16}$ SCHMITT, Carl. O Conceito do político. Teoria do Partisan. Del Rey: Ed. Belo Horizonte, 2008. p. 38.
} 
Europa ocidental ante o desenvolvimento de um novo hegemon sob a égide de Washington. O período entreguerras, marcado pela Crise de 1929 e pelo advento dos extremismos e dos governos de massa (fascismo, nazismo, comunismo e Welfare State), molda as bases para o conflito mundial subsequente, uma guerra ainda mais brutal e o maior morticínio já registrado na história.

Talvez o grande marco de aquisição de uma natureza "total" por parte da Segunda Guerra Mundial seja a invasão da União Soviética pela Alemanha nazista, que, por sua vez, já se encontrava em combate com as potências ocidentais. Após séculos de czarismo, o recém-fundado gigante vermelho ainda enfrentava as dificuldades para superar as consequências do modelo econômico semifeudal da Rússia imperial e reaver um status efetivo de potência mundial. $\mathrm{O}$ avassalador poderio bélico alemão impusera, de início, violentas derrotas aos soviéticos, que não tiveram alternativas senão recorrer à guerra total. Todas as forças da União Soviética foram mobilizadas à guerra. Não à toa o conflito é até hoje reconhecido entre os russos como a Grande Guerra Patriótica (Вели́кая Оте́чественная война́).

Quando do histórico discurso do ministro da Propaganda do Reich, Joseph Goebbels, no Sportapalast e da declaração da Alemanha de guerra total ("Wollt ihr den Totalen Krieg?") 17 ante a uma inesperada reviravolta soviética, se deflagrara, portanto, o estado de plena mobilização de recursos e esforços na Alemanha. Para os alemães era, então, iniciada a Guerra Total. Para os soviéticos, esta já era uma realidade há muito tempo.

É preciso destacar, contudo, que o conceito de Guerra Total ainda carece de uma robustez teórica, tendo sido utilizado ao longo das décadas de forma demasiadamente vulgar, cumprindo função de propaganda política - vide o caso supramencionado -, ainda que descrevesse um fenômeno real. No afã de se teorizar o que seria uma guerra de natureza "total", muitos autores tentaram estabelecer premissas a partir das quais se poderia classificar uma guerra como "guerra total".

Como supracitado, Morgenthau (2003) estebelece quatro aspectos pelos quais a guerra moderna se tornou total. Estes aspectos, contudo, devem ser acrescidos ao caráter fundamental do progresso tecnológico, uma vez que o advento das novas tecnologias é um fator indissociável da conversão da guerra parcial em guerra total. O papel de centralidade da técnica, do aparato material e da indústria na guerra moderna, é o ponto-chave para compreender a nova natureza da guerra, profundamente marcada pela impessoalidade e pela aniquilação. Sobre o tema, recorramos a António Duarte (2005):

A este factor político-militar outro se reúne. A Grande Guerra demonstrou o papel central da realidade material, do factor industrial e tecnológico, da máquina como substituto do homem. A filosofia alemã, desde Nietzshe pelo menos, mais tarde com Heidegger e Junger, tornou central ao seu discurso a complexa relação entre a técnica e o totalitarismo. Junger, principalmente, fez da análise da Grande Guerra e do impacto da técnica nesta, um dos elementos para a compreensão do Mundo moderno, para a afirmação de um universo onde a técnica dominando o homem, o subordina ao seu pathos, aniquilando o indivíduo e com ele a possibilidade de liberdade. Para o autor, apesar de tudo, o "mito" do soldado desconhecido ainda podia fazer perviver o ideal de heróis conquistadores de mundos ígneos, coisa que a Segunda Guerra Mundial, puramente mecânica e automatizada inviabilizava. Era, paradoxalmente para Junger, o triunfo total da lógica da Guerra Total.

\footnotetext{
${ }_{17} \mathrm{Em} 18$ de fevereiro de 1943, antes de uma inesperada reviravolta na Segunda Guerra Mundial, o ministro da Propaganda do Reich, Joseph Goebbels, declarava Guerra Total em histórico discurso no Sportpalast, em Berlim. Especula-se que o discurso tenha sido planejado por Goebbels ainda no ano anterior, quando começara a se delinear a derrota alemã em Stalingrado. Goebbels evocava a presença de um inimigo judaico-bolchevique, ante o qual as democracias ocidentais se mostravam fracas e incapazes de impedir o controle, restando unicamente à Alemanha a possibilidade de impedir um domínio judaico e comunista de todo o mundo. Em meio a esta disputa de valor quase que escatológico, a Alemanha lidaria agora com um quadro de derrota e vantagem soviética, uma vez que os vermelhos venciam o cerco e iniciavam a grande reviravolta na Guerra. Aos alemães somente restava uma alternativa: a Guerra Total (der Totale Krieg), isto é, mobilizar todas as forças e recursos do país para a guerra. Goebbels afirma que as democracias ocidentais divulgam que o governo alemão quer a Guerra Total em detrimento de seu povo, que supostamente clama pela capitulação. O público presente grita "não" e aclama fervorosamente (Kapitulieren? Nein). O ministro, então, proclama a indagação que entraria para história: "Vocês querem guerra total?" E, ainda: "Vocês a querem, se necessário, mais total e radical do que a podemos imaginar hoje?". Em ambas as perguntas o ministro fora interrompido por gritos fanáticos de "sim!" e aplausos. Para os alemães, era o início da Guerra Total. Para os soviéticos, era a sua continuação. Para saber mais sobre o tema, ver, dentre outras fontes: HERF, Jeffrey. The "Jewish War": Goebbels and the Antisemitic Campaigns of the Nazi Propaganda Ministry. Holocaust and Genocide Studies, vol. 19, n. 1, p. 51-80, 10 mar. 2005.
} 
A percepção do que é Guerra Total, contudo, tende a variar entre os autores e suas respectivas nacionalidades de acordo com as experiências de cada nação no fenômeno da guerra moderna. Para os alemães, Guerra Total significa a dinâmica do material (Materialschlacht). Por outro lado, as demais partes envolvidas nos conflitos divergiam em interpretações do mesmo fenômeno:

Para facilitar a síntese, é talvez conveniente apresentar a interpretação que os diversos decisores estratégicos institucionais fazem da Grande Guerra e da "Guerra Total" à luz do conceito chave, de uma ideia força, que funciona como metáfora ou arquétipo de sua racionalidade estratégica. Assim, para os anglo-saxões (EUA e GB) a Guerra Total é, antes de mais nada, uma questão de recursos; para os franceses o assento é dado ao fogo, enquanto que para os alemães o que se sobressai é a dinâmica do material e para os sovieto-russos o acento é na massa (física e geográfica) (DUARTE, 2005).

O fator determinante da Guerra Total, que prevalece em todas as concepções da mesma, é a mobilização total, isto é, mobilização máxima de recursos humanos e materiais com fins bélicos. É nesta perspectiva que Leon Daudet, em La Guerre Totale (1918-2008), ${ }^{18}$ conclui que a Guerra Total é a mobilização de toda a sociedade com vistas ao afrontamento entre as nações. ${ }^{19}$

Em verdade, ao fim das Guerras Mundiais - da experiência de 30 anos de Guerra Total - a ordem mundial até então vigente estava liquidada. Saíam vitoriosas do conflito duas potências mundiais ideologicamente antagônicas. Era o fim do ordenamento vestphaliano e o começo de uma ordem geopolítica bipolar, na qual todos os países do globo escolhiam, pela própria prudência, a qual bloco mundial integrar e viver sob quase irrestrita influência. A Liga das Nações, criada no período entreguerras para impedir uma nova experiência de Guerra Total, é substituída, após seu fracasso, pela Organização das Nações Unidas, que monopoliza, liquidada a lei de Vestfália, o direito da guerra sob um Conselho de Segurança, assumindo a guerra, a partir de então, um caráter criminal com uma formal extinção do direito de se fazer guerra, que, em outras e melhores palavras, pode ser também dita como uma monopilização desse direito em um selecionado internacional de potências globais, à época, antagonizadas em dois polos, e, após 1991, integralizadas no universo liberal.

O mérito do presente estudo é relacionar o fenômeno da Guerra Total com a guerra-de-todos-contra-todos, careacterística do estado natural hobbesiano. Tal qual a mítica reunião de indivíduos livres para a celebração do Contrato que criaria o Estado - o Grande Leviatã - se reuniram as nações nos Estados Unidos da América, em 1945, para a fundação da Organização das Nações Unidas, o Leviatã Mundial. Os Estados se convertem em indivíduos e a reunião das nações em assembleia se converte no Estado. $O$ estado de natureza se converte no mundo vestfaliano e a guerra-de-todos-contra-todos se converte na Guerra Total.

Por quase meio século, contudo, o mundo enfrentaria o que se chamou de guerra fria. Um conflito não armado e não declarado entre Estados Unidos e União Soviética com fins de hegemonia global, exercendo influência em conflitos regionais, engajando-se em corridas científicas e tecnológicas, empreendendo uma forte campanha de soft power e assombrando todos os povos com uma constante ameaça de guerra nuclear. Com a queda da URSS e o soterramento histórico do socialismo soviético, a ordem geopolítica é reconfigurada sob a égide de um único polo ocidental, liberal e estadunidense. Com os Atentados de 11 de Setembro de 2001, os EUA empreendem uma guerra global ao terrorismo, utilizando desmedidamente de seu poderio militar e de sua influência ideológica para, inclusive com a violação do Direito Internacional quando conveniente, ${ }^{20}$ garantir seus interesses travestidos de uma cruzada humanitária internacional contra o terror.

A Guerra ao Terror configura uma nova mudança no paradigma da Guerra em sua evolução histórica, assumindo o caráter máximo da Guerra transnacional, territorialmente descontínua e multifacetada. Suas implicâncias para o Direito Internacional, porém, ademais de não constituírem tema do presente estudo, ainda não se demonstram palpáveis, restando apenas previsões de teor especulativo.

\footnotetext{
18 DAUDET, Leon. La Guerre Totale. Montana: ,2008 (1918).

${ }^{19}$ DUARTE, António Paulo. A visão da "guerra total" no pensamento militar. Nação \& Defesa, 3. série, n. 112, outono-inverno 2005. p. 33-50.

${ }^{20}$ Vide Guerra do Kosovo (1998-1999) e Invasão do Iraque (2003).
} 


\section{DE VESTFÁLIA A NUREMBERG}

Rememorando os tópicos até aqui abordados, o conjunto de tratados eternizado como "Paz de Vesfália" soterrou a antiga ordem jurídica e política europeia da Respublica Christiana, dando lugar ao ordenamento dos Estados soberanos, que, à medida dos interesses da burguesia emergente, favoreciam o desenvolvimento do sistema capitalista, que então necessitava do resguardo estatal para seu florescimento e afirmação enquanto modelo econômico, pondo um definitivo fim ao velho modelo europeu, baseado no catolicismo romano e na cultura feudal. Como se sabe desde pelo menos Max Weber (1864-1920) e sua Die Protestantische Ethik und der Geist des Kapitalismus (1905), a espiritualidade protestante forneceu uma sólida base metafísica ao despertar do capitalismo, cabendo, porém, também ressaltar o princípio epistemológico norteador do arcabouço ideológico do sistema nascituro, a saber, o individualismo, cujas bases remontam à Escolástica. ${ }^{21}$

Com o enfraquecimento do Sacro Império Romano-Germânico e da Igreja Católica, o reconhecimento do calvinismo e o surgimento de um sistema de Estados soberanos demarcados por fronteiras artificiais invioláveis, a Paz de Vestfália inaugurou um formato de sociedade internacional que permitiu o desenvolvimento do sistema capitalista em uma fase inicial, que sofreria drásticas mudanças com o advento do capitalismo industrial (século 18), que, tendo como sua consequência a necessidade de aquisição de mercado consumidor para a produção - bem como um alargamento das fontes de recursos materiais e humanos -, impulsionou a expansão supranacional do capitalismo, cuja primeira expressão fora o advento do imperialismo neocolonialista e a partilha de territórios na África e na Ásia (século 19). A partir de então, as fronteiras artificiais do modelo vestfaliano, outrora indispensáveis ao capitalismo, tornam-se um obstáculo a seus novos rumos e ambições. Nesse campo, o internacionalista argentino Marcelo Gullo trabalha sua Teoria do Umbral do Poder, segundo a qual, a história da construção do poder entre as nações pode ser visualizada por meio de estágios mínimos a serem alcançados para a conquista da real soberania dos países em cada época, tendo sido o primeiro estágio a constituição de um Estado Nacional, o segundo a industrialização e o terceiro a aquisição de territórios (sendo sucedido pela posse da bomba atômica após as Guerras Mundiais e o desenvolvimento de novas tecnologias na contemporaneidade)..$^{22}$

O resultado direto da fase imperialista do capitalismo é a Primeira Guerra Mundial, que demonstra os sinais mais fortes da crise do modelo vestfaliano até então registrados. É então que surge a primeira experiência de Guerra Total, abalando todo um ordenamento previamente estabelecido por intermédio de uma nova modalidade bélica jamais registrada outrora. Após a Primeira Grande Guerra, os vitoriosos reuniram-se numa tentativa de estabelecer uma "paz dos vitoriosos", expressa com grande perspicácia no Tratado de Versalhes, com suas abusivas imposições e restrições à derrotada Alemanha, e na criação da Liga das Nações, a primeira tentativa de se "corrigir" o sistema vestfaliano em prol de uma sociedade internacional mais justa e com força suficiente para assegurar a paz. O flagrante fracasso da Liga culminou na incapacidade de impedir um conflito com a magnitude da Segunda Guerra Mundial, ainda mais avassaladora do que a antecessora, e que dissolveu definitivamente o ordenamento vestfaliano ao evidenciar os perigos da soberania estatal irrestrita. Isto se expõe, uma vez que os atos perpetrados pela Alemanha nazista, de indubitável repulsa universal, não constituíam ao tempo de sua execução qualquer ilícito, sendo consagrados pelo ordenamento interno.

Ainda assim, os Aliados estabeleceram os Tribunais Militares de Exceção em Nuremberg e Tóquio (19451946) para julgar aqueles a que consideram culpados pela Guerra e pelos massacres. Desconsiderando uma análise profunda sobre o episódio em Tóquio e dando maior foco aos Julgamentos de Nuremberg em razão de sua inegável maior relevância para o Direito Internacional, é necessário que se estabeleça uma discussão fria e secular em torno do tema, sem incorrer em paixões ideológicas ou em irracionalismo emotivo. Em verdade, ainda que se leve em consideração o teor de barbaridades denunciadas em Nuremberg, a legitimidade do Tribunal ali estabelecido somente pode ser construída com tamanho esforço teórico e, para tal fenômeno, foi

\footnotetext{
${ }^{21}$ Sobre este tema, ver: DE ALMEIDA, Lucas Leiroz. Da existência de um totalitarismo liberal-humanitário após 70 anos da Declaração Universal dos Direitos Humanos. Revista Jus Navigandi, ISSN 1518-4862, Teresina, ano 23, n. 5.379, 24 mar. 2018. Disponível em: https://jus.com. br/artigos/64898.

${ }^{22}$ Ver: GULLO, Marcelo. La Insubordinación Fundante: Breve historia de la construcción del poder de las naciones. Biblos, 1. ed. 5 nov. 2008.
} 


\section{Debate}

necessário cunhar uma nova terminologia, a saber, os chamados grotian moments, ${ }^{23}$ que, em referência ao jurista considerado o pai do Direito Internacional, Hugo Grócio (1583-1645), aludem a determinados momentos na história do Direito Internacional em que uma ilegalidade ou ilegitimidade se torna justificada por certo teor de "consenso" ante uma aparente necessidade. Nuremberg foi um "momento grociano"; um momento de recriação do Direito Internacional. O Tribunal ilegal se legitimou por um "consenso" (dos vencedores) sobre a necessidade de se punir os derrotados.

Para tratar do tema do Tribunal de Nuremberg, deve-se recorrer à doutrina italiana de Antonio Cassese (2005), com o qual verifica-se a existência do fenômeno da Síndrome de Nuremberg, que consiste na perpetuação do modelo de "justiça dos vitoriosos" na esfera das Cortes Internacionais. Danilo Zolo (2007) também toma a referida ideia por pressuposto em sua tese sobre a existência de um "duplo binário", cuja estrutura se organizara ao fim da Segunda Guerra Mundial, eternizando um sistema de justiça dos vitoriosos, no qual um grupo de poderosas potências mundiais, camufladas sob o véu do Conselho de Segurança das Nações Unidas, rivaliza contra um polo de nações derrotadas e subjugadas. ${ }^{24}$

Em suma, Nuremberg, com seus Tribunais de Exceção, encerra definitivamente o mundo que nascera em Vestfália com os tratados internacionais que puseram fim à Guerra dos Trinta Anos e inauguraram um ordenamento jurídico internacional de Estados Soberanos. Em uma linha do tempo genérica, após o desmantelamento da Respublica Christiana, a ordem dos Estados-Nação é estabelecida em Vestfália e sobrevive até o advento da Guerra Total, que revela as fragilidades do sistema de soberania estatal irrestrita no século 20, sendo o mesmo enfraquecido pela Liga das Nações e, definitivamente, encerrado no transcurso dos Julgamentos de Nuremberg e do advento das Nações Unidas, que fomentam o novo e vigente ordenamento internacional, flagrantemente marcado pelo universalismo jurídico do Leviatã Mundial, que diminui consideravelmente a soberania dos Estados em prol de maiores segurança e justiça na esfera internacional.

\section{CONSIDERAÇÕES FINAIS}

Tradicionalmente, a história do Direito Internacional Público é tratada numa perspectiva linear e evolutiva, de modo a fazer uso do discurso do progresso universal. Em regra, há a ideia de que o Direito Internacional evoluiu ao longo de sua história rumo a um estado de maior seguridade entre as nações e garantias mínimas universais com a ideologia dos Direitos Humanos. Como ficou evidente no presente estudo, porém, a ordem jurídica internacional contemporânea apresenta-se como resultado da catástrofe universal deflagrada pelo fenômeno da Guerra Total no século 20, que pôs fim ao ordenamento vestfaliano, evidenciando suas fraquezas e requerendo o advento de um novo Direito Internacional.

A Guerra Total consiste em um fenômeno típico da natureza da guerra moderna, englobando seus traços de profunda mobilização de recursos humanos e materiais. A Guerra Total caracteriza-se pela completa movimentação da sociedade para o fim de não apenas derrotar e subjugar o inimigo, mas de buscar sua plena aniquilação, englobando também a sociedade civil, que se converte em inimiga tal qual o contingente militar.

A partir das experiências de Guerra Total torna-se flagrante a necessidade de um novo Direito Internacional. A Guerra Total transporta para o cenário internacional a realidade dos indivíduos do estado de natureza de Thomas Hobbes. De igual maneira, a criação das Nações Unidas transporta para o mesmo cenário o Leviatã hobbesiano.

Evidenciou-se, também, que o Tribunal de Nuremberg instaurou um novo modelo de jurisdição internacional, que, mais tarde, viria a ser consolidado e perpetuado com as Cortes de Haia. Nesse sistema nurembergniano, perdura um duplo-binário, no qual nações poderosas do Ocidente liberal impõem seus interesses na esfera internacional pela práxis jurídica, incorrendo mesmo, por vezes, na violação das normas vigentes. Violações estas que, pela força dos agentes violadores, passam a constituir novas regras, os chamados grotian moments.

\footnotetext{
${ }^{23}$ Sobre o conceito de Grotian Moment, ver: STERIO, Milena. A Grotian Moment: Changes in Legal Theory of Satatehood. Denver Journal of International Law and Policy, 39, 209, 2011.

${ }^{24}$ Sobre o tema, rever obras suprarreferidas de ZOLO (2007) e CASSESE (2005).
} 
O mundo vestfaliano dá lugar ao mundo nurembergniano. A ordem dos Estados-Nação cede espaço ao ordenamento leviatânico do universalismo jurídico das Nações Unidas. Antes, sob o cenário da Guerra Fria e da geopolítica bipolar, Estados Unidos e União Soviética contrabalanceavam o monopólio do uso da força no cenário internacional, contrapondo seus interesses com seus respectivos aliados na ONU. Após o fim do comunismo, o liberalismo se universaliza, tendo aniquilado toda e qualquer forma de oposição política. Chega-se, então, àquilo que Francis Fukuyama (2005) chamou de $O$ Fim da História.

O universalismo liberal desconectou o estado vigente de sua construção histórica e o alienou de seus alicerces ideológicos, criando um estado geral de "normalidade". A democracia liberal, o Estado de Direito e o capitalismo são universalizados, e sua tutela é reservada ao eixo ocidental, que assume um caráter de "guardião constitucional universal".

A Guerra Total gerou também o controle total e, consequentemente, o totalitarismo universal dos vencedores da Guerra e dos acusadores-julgadores de Nuremberg. Como resultado, vive-se sob aquela que talvez seja a mais frágil ordem política internacional de que se tem registro, quando o poderio concentrado nas mãos de poucos países pela geopolítica unipolar gera um constante estado de insegurança coletiva entre os povos e a generalizada submissão de Estados soberanos a interesses externos.

Como não se poderia deixar de citar, a guerra, na contemporaneidade, assume um caráter global (ZOLO, 2007). Os inimigos dos acusadores-julgadores de Nuremberg se convertem em inimigos gerais da humanidade, sendo a própria "humanidade" uma característica da qual são excluídos. Aos que se opõem à axiologia ou a práxis do establishment, resta a mesma Guerra Total. E aqueles que, eventualmente, sejam derrotados pelo poder hegemônico, aguardam em Haia o que sucedera aos alemães em Nuremberg.

É possível pensar alternativas ao quadro vigente a partir das mais diversas perspectivas. As variações no âmbito da geopolítica e das Relações Internacionais tendem a ocasionar novas mudanças no campo do Direito Internacional. As evidências do surgimento de um ordenamento multipolar são cada vez mais bem-aceitas na Academia e, em breve, demandarão novos estudos com fins de se estabelecer uma nova possibilidade jurídica para esta outra realidade.

Por fim, resta mencionar que a Guerra Total continua a ser parte da realidade do mundo contemporâneo, e, por certo, encontra hoje sua face mais ameaçadora ante a possibilidade de um conflito armado com as tecnologias vigentes. É necessário, pois, conhecer a história e a formação do Direito Internacional para que se possa fortalecê-lo, superar suas crises e fraquezas e caminhar firmemente rumo a um mundo mais seguro e de maior estabilidade da paz entre os povos.

\section{REFERÊNCIAS}

BELL, David. The First Total War: Napoleon's Europe and the Birth of Warfare as We Know It. 1. ed. Boston: Houghton Mifflin Co., 2007.

BÍBLIA. A Bíblia Sagrada: Antigo e Novo Testamento. Trad. João Ferreira de Almeida. Edição rev. e atualizada no Brasil. Brasília: Sociedade Bíblia do Brasil, 1969.

CASSESE, Antonio. II Processo a Sadam e i Nobili Fini della Giustizia. In: La Repubblica, 19 out. 2005.

DAUDET, Leon. La Guerre Totale. Montana: Kessinger Publishing, LCC, 1918-2008.

DE ALMEIDA, Lucas Leiroz. Da existência de um totalitarismo liberal-humanitário após 70 anos da Declaração Universal dos Direitos Humanos. Revista Jus Navigandi, Teresina, ano 23, n. 5.379, 24 mar. 2018. ISSN 1518-4862. Disponível em: https://jus. com.br/artigos/64898. Acesso em: 2 mar. 2019.

DUARTE, António Paulo. A visão da "guerra total" no pensamento militar. Nação \& Defesa. 3. série, n. 112, outono-inverno, 2005.

FUKUYAMA, Francis. O fim da história e o último homem. 1. ed. Rio de Janeiro: Rocco, 2005.

GORMAN, James. Prehistoric Massacre Hints at War Among Hunter-Gatherers. The New York Times, 21 Jan. 2016. Available from: https://www.nytimes.com/2016/01/21/science/prehistoric-massacre-ancient-humans-lake-turkana-kenya.html. Cited: 20 fev. 2019.

GUERRA, Sidney. Curso de direito internacional público. 11. ed. São Paulo: Saraiva, 2017.

GULLO, Marcelo. La Insubordinación Fundante: Breve Historia de la Construcción del Poder de las Naciones. Biblos, 1. ed. 5 nov. 2008. 


\section{Direito Debate}

HERF, Jeffrey. The "Jewish War": Goebbels and the Antisemitic Campaigns of the Nazi Propaganda Ministry. Holocaust and Genocide Studies, v. 19, n. 1, 1ㅇ Mar. 2005.

HOBBES, Thomas. Leviatã ou matéria, forma e poder de um estado eclesiástico e civil. 1. ed. São Paulo: Edipro, 2015.

HOBSBAWN, Eric. A era dos extremos: o breve século XX. 1914-1991. 2. ed. São Paulo: Companhia das Letras, 1995.

MORGENTHAU, Hans J. A política entre as nações: a luta pela guerra e pela paz. Brasília: Editora Universidade de Brasília/ Instituto de Pesquisa de Relações Internacionais; São Paulo: Imprensa Oficial do Estado de São Paulo, 2003.

SCHMITT, Carl. El Nomos de la Tierra en el Derecho de Gentes del "Jius Publicum Europaeum". Buenos Aires: Struhart \& Cia., 2005.

SCHMITT, Carl. O conceito do político. Teoria do Partisan. Belo Horizonte: Del Rey Ed., 2008.

SINGER, David. The Wages of War 1816-1965: A Statistical Handbook. Nova York; Londres; Sidney; Toronto: John Wiley \& Sons, 1972.

STERIO, Milena. A Grotian Moment: Changes in Legal Theory of Satatehood. Denver Journal of International Law and Policy, 39, 209. 2011.

TEIXEIRA, Anderson Vichinkeski. Teoria pluriversalista do Direito Internacional. 1. ed. São Paulo: WMF Martins Fontes, 2011. VON CLAUSEWITZ, Carl. On War. Oxford: Oxford University Press, 2007.

WEBER, Max. Die Protestantische Ethik Und Der Geist Des Kapitalismus. 4. ed. Berlim: Createspace Independent Publishing Platform, 2016.

ZOLO, Danilo. La Justicia de los Vencedores: de Nuremberg a Bagdad. Madrid: Ed. Trotta, 2007. 